研究

\title{
プラズマ窒化による Fe-Cr合金の組織及び硬さ傾斜の制御
}

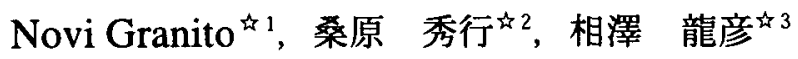 \\ 的東京大学工学研究科金属工学専攻, T 113-8656 文京区本郷 7-3-1. \\ 4 2 応用科学研究所, $\bar{T} 606-8202$ 京都市左京区田中大堰町 49 . \\ 和 東京大学先端科学技術研究センター, 厂 153-8904 目黒区駒場 4-6-1.
}

\section{Microstructure and Graded Hardness Control in Fe-Cr Alloy by Plasma Nitriding Technique}

\author{
Novi Granito ${ }^{\text {म1 }}$, Hideyuki Kuwahara ${ }^{\text {2 }}$ and Tatsuhiko Aizawa \\ ${ }^{* 1}$ Graduate School of Engineering, The University of Tokyo, 7-3-1 Hongo, Tokyo 113-8656. \\ ${ }_{4}^{2}{ }^{2}$ Research Institute for Applied Science, Tanaka-Ohicho, Sakyo-ku, Kyoto 606-8202. \\ \& 3 Research Center for Advanced Science and Technology, The University of Tokyo, 4-6-1 Komaba, Tokyo 153-8904.
}

Received January 10, 2001

\section{SYNOPSIS}

$\mathrm{Fe}-\mathrm{Cr}$ alloys have been nitrided by plasma process in the temperature range of 773 to $893 \mathrm{~K}$ to develop a controlled nitrided microstructure. Typical microstructures of nitriding layers were observed on the cross section of specimens plasma nitrided at temperature below $823 \mathrm{~K}$. A novel nitriding layer of stripe pattern was observed on the cross section of $\mathrm{Fe}-13 \mathrm{Cr}$ alloy, which was plasma nitrided at $873 \mathrm{~K}$ for $176.4 \mathrm{ks}$. This microstructure consisted of sublayers, which seems to have different dissolved chromium content each other. Also it was observed that the hardness gradually increased from the specimen surface toward the nitriding front before changed sharply to the same level as matrix hardness. Such phenomena can not be explained only by nitrogen diffusion process during the nitriding, but also diffusion of alloying elements i.e. Cr should be considered to contribute significantly to the stripe-pattern microstructure. A series of frictional wear examination result showed that such nitrided layer properties should be a good candidate for improving wear resistance.

KEY WORDS

plasma nitriding, graded hardness, chromium diffusion

\section{1 粕 言}

鉄鋼材料の硬さ, 耐摩耗性, 瘦労強度の向上, あるいは耐 食性の向上のために多種多様な表面改質技術がある. 中でも 窒化処理はいろいろな機械部品や自動車部品などに適用され ている. 窒化処理時間の短縮化, 窒化処理用ガス消費量の低 減や窒化首組織の制御性を容易にするために, 窒化技術の中 でも，近年は特にプラズマ窒化技術が種々の分野での機械部 品機能向上のために用いられることが多くなっている ${ }^{1-4)}$. し かし, 空化機構や窒化首組織が十分に解明されていない部分 も残されており5), これらの解明が強く望まれている.このた めには, プラズマ空化機構の詳細な解明を行う必要があり, プラズマ窒化層組織についての組織学的研究の必要性がある. さらに, プラズマ窒化は窒化層組織の制御性が容易であるこ とから, 従来の窒化法に比較して, より高性能の表面材料設 計ができることが期待される.

一般的な鉄銅材料の窒化では, 表面に鉄窒化物の層を数 $\mu \mathrm{m}$ の厚さで形成する. この鉄空化物の層は, 外部空化層と呼ば
れている.さらにこの外部窒化層の内側に窒素を固溶したマ トリックス中に合金窒化物を析出した数百 $\mu \mathrm{m}$ の厚さの内部 窒化首が形成される( 温度, 空化時間, カス組成と圧力などの窒化条件と合金組成 に大きく影整される ${ }^{7,8)}$.

一般機械構造用低合金鎆の実用面から考えると，耐摩耗性 改善のための材料表面改質設計のあり方についての概念をど のように構筑するかは極めて工業的に重要なことである. 室 化首の典型例は, 外部窒化層で最大硬さを示し, その内部に 続く内部窒化層における硬さは未空化層の硬さへと連続的に 徐々に変化することはよく知られている.しかし，このよう な硬さ分布では面圧の高い摩擦条件において亀裂が発生する と容易に窒化層先端にまで達するので, 高面圧摩擦する機械 部品の応用には向いていない9.このような条件に耐えるよう にするためには，新しい表面構造組織材料を創製して耐摩耗 性の向上と摩擦係数の低减を同時に計る必要がある.このた めに, 例えばPVD法により $\mathrm{CrN}$ の硬い層と䩚性のある比較的 
柔らかいCr層を交互に積首することによって優れた耐摩耗性 を示した報告がある ${ }^{10}$. このような方法は二次元的な表面構 造組織を形成したといえるが, 高面圧が負荷され且つ回転や 摺動などの運動を行うような機械部品においてはその応力が 三次元の分布をしており,これに応答できる表面構造組織設 計が求められている. そのためには, プラズマ窒化によって 窒化層の組織制御を行ない, 高面圧の負荷に耐え得る三次元 表面構造組織を実現する必要があると考えられる。

上記のような三次元表面構造組織設計の実現のために, 窒 化層の組織制御の可能性を検討する必要がある.このために, 制御因子の溶質原子の単純化と制御因子の確保, 即ち, $\mathrm{Fe}-\mathrm{Cr}$ 二元系合金とすることによって溶質元素を $\mathrm{Cr}$ 一種類として単 純化を計る一方, $\mathrm{Fe}-\mathrm{Ti}$ 二元系合金のように窒化に伴い溶質原 子であるTiの全てがTiNとして析出するよりも溶質原子の Cr の一部は析出窒化物として母相中に分散析出し, また残りの $\mathrm{Cr}$ 原子は固溶 $\mathrm{Cr}$ として母相 $\mathrm{Fe}-\mathrm{Cr}$ 二元系合金を構成すること によって現象の単純化と制御の自由度を確保して, 三次元表 面構造組織設計の実現の検討を行うことにした.このような 目的に到達するためにまず本研究では, $\mathrm{Fe}-\mathrm{Cr}$ 合金を用いて, $773 \mathrm{~K}$ から $873 \mathrm{~K}$ の温度域においてプラズマ公化することにし た. $\mathrm{Fe}-\mathrm{C}$ 系を窒化すると, 全ての固溶元素 $\mathrm{Ti}$ が窒化物とな る Fe Ti 合金の場合と異なり, 窒化先端では一部の Crが固溶 状態のままとなり，特に低Cr合金ではこれが窒化層の硬さ傾 斜をもたらすという報告があった ${ }^{12) . ~}$ Cr挙動に注目をし, 窒化温度変化による窒化組織へのCrの影 響を検討し，新しい窒化特性を見出すことを目的とした。

\section{2 実験方法}

供試材に Fe-13Cr 合金 (C: 0.002, Si: 0.22, Mn: 0.01, P: 0.001, S: 0.001, Cr: 13.68, Al: 0.001, Ti: 0.026, N: 0.0007, O: 0.004) を用 いた. 試料を $10 \times 10 \times 20 \mathrm{~mm}^{3}$ に切出してからエメリ一研磨試 \#1000 まで研磨後に, 平均粒径 $1 \mu \mathrm{m}$ のダイヤモンドペースト でバフ研磨した. その後にアセトン中で10分間超音波洗净を 行った.

プラズマ窒化は，水素分圧 $399 \mathrm{~Pa}$ と窒素分圧 $133 \mathrm{~Pa}$ のカス 雾囲気中で直流電圧-300Vを試料に印加して直流グロー放電 を発生させて, 試料温度を773,823,873Kに加熱保持して行っ た. 尚, 窒化中のプラズマ条件(ガス分圧と全圧, 放電電圧と 電流 ) は一定に保ち, 試料温度は真空槽内に設けたヒー夕に よって変化させた。

用いたプラズマ公化装置の概略をFig.1に示す. 試料を設置 する試料台は高電圧陰極であり，真空槽と電気的に絶縁され ている. 真空槽は陽極に接続されて接地されている。試料を 試料台に設置後，ロータリーポンプで真空槽内を $3 \mathrm{~Pa}$ まで排 気してから，399Pa まで水素を導入した．その後，ヒータで 加熱を開始すると同時に試料に直流電圧を印加して水素プラ ズマも併用して試料を所定の温度まで加熱してから，窒素を $133 \mathrm{~Pa}$ まで導入して全圧力を $532 \mathrm{~Pa}$ とした．この窒素ガスを 導入した時点を窒化開始時間とした．また，窒素カス導入
中に印加電圧を注意哚く-300Vになるように調整した. 試料 温度は同程度の大きさのダミ一試料に石英管で電気的に絶縁 された電気絶縁型シース熱電対を挿入して計測し，ヒータへ の電力を制御した． 所定の時間プラズマ窒化してから，窒素 ガスの導入を停止して $399 \mathrm{~Pa}$ の水素ガス気流中で試料を室温 まで冷却した。

窒化した試料を窒化方向に平行にマイクロカッターで切断 し，この切断面を鏡面に研磨後，試料表面近傍から試料内部 へ窒化方向に平行にビッカース硬さ (測定荷重 $0.98 \mathrm{~N}$, 測定荷 重負荷時間 30 s) 分布を測定した。.また，同じ断面において腐 食液 $\left(5 \mathrm{~g} \mathrm{FeCl}_{2}+2 \mathrm{ml} \mathrm{HCl}+96 \mathrm{ml} \mathrm{C} \mathrm{C}_{5} \mathrm{OH}\right)$ で腐食して光学顕微 鏡 (ニコン製型) と走查型電子䫒微鏡 (日立製 S800 型, Philips 製EDAX分析器-ECON NとEDAM 附属)を用いて組織観察 を行ってから，試料断面におけるCr濃度分布を調べるために エネルギー分散法(EDX)による分析を行った. 濃度分析は試 料断面に执いて窒化方向に幅 $10 \mu \mathrm{m}$ ごとに加速電圧 $20 \mathrm{kV}$, 取 り出し角度 $34.57 \mathrm{deg}$ で行った. 試料窒化表面においてX線回折 によって相の同定を行った．また，窒化した試料の耐摩耗性 をスカッフ試験で評価した。スカッフ試験は荷重を $0.083 \mathrm{~kg} / \mathrm{s}$ の割合で増加して行った。

\section{3 実験結果および考察}

3.1 窒化温度 $773 \mathrm{~K} \leq \mathrm{T} \leq 823 \mathrm{~K}$ における窒化組織

$\mathrm{Fe}-13 \mathrm{C}_{\mathrm{r}}$ 合金を $773 \mathrm{~K}$ で $57.6 \mathrm{ks}$ プラズマ窒化した試料の断面 における窒化層組織を Fig.2に示す．図中の S は試料表面を， $\mathrm{F}$ は窒化首先端を，Eは窒化層の厚さをそれぞれ示している. 外部空化層の厚さは $2-3 \mu \mathrm{m}$ 程度あり, 内部窒化層の厚さは約 $120 \mu \mathrm{m}$ と計測される.このような空化層組織は既に高田ら ${ }^{111}$ によって報告されている組織と同様である．従って，上の窒 化層組織も空素の体拡散によって窒化層が成長した結果を示

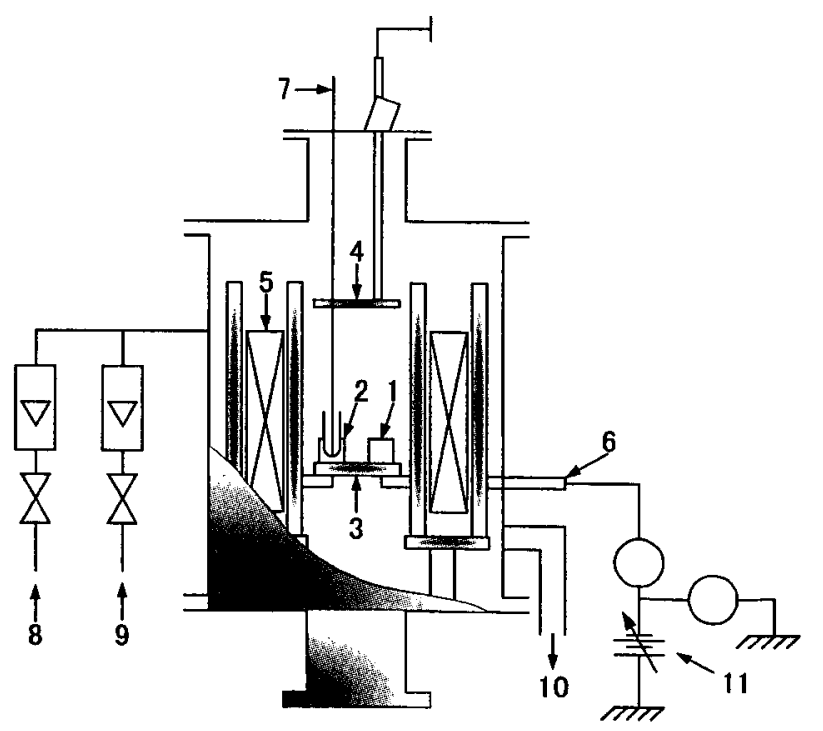

Fig.1 Schematic illustration of plasma nitriding apparatus. (1) Specimen, (2) Dummy specimen, (3) Specimen table, (4) Anode, (5) Heater, (6) Cathode, (7) Thermocouple, (8) $\mathrm{N}_{2}$ gas inlet, (9) $\mathrm{H}_{2}$ gas inlet, (10) To rotary pump. 


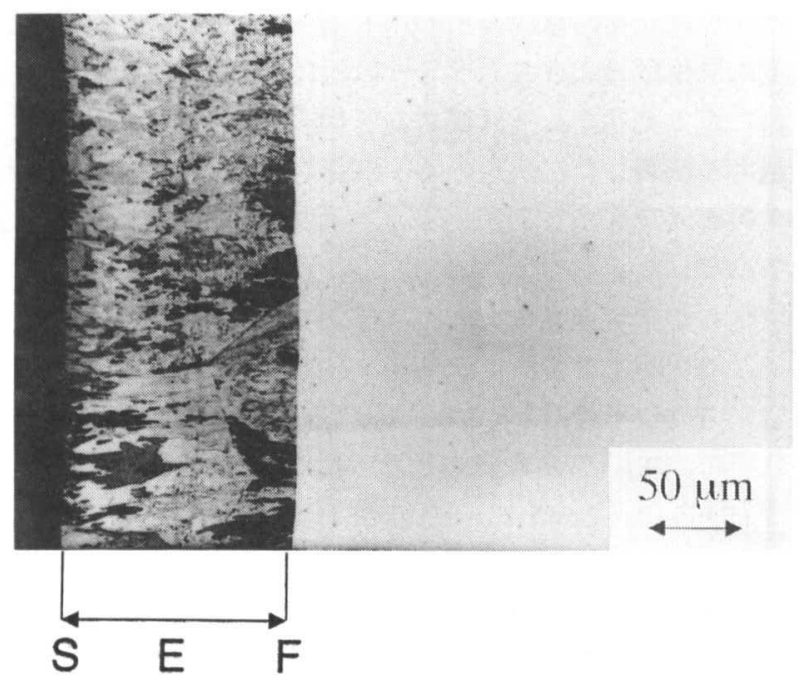

Fig.2 Microstructure of $\mathrm{Fe}-13 \mathrm{Cr}$ after plasma nitrided at $773 \mathrm{~K}$ for $57.6 \mathrm{ks}$.

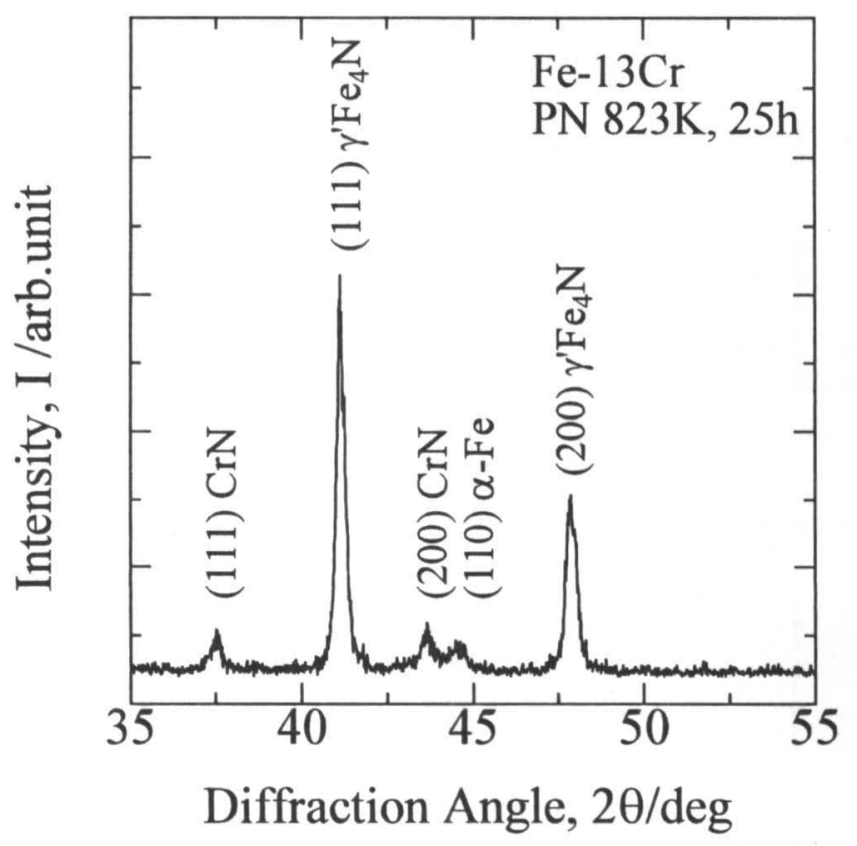

Fig. 3 XRD pattern on the surface of $\mathrm{Fe}-13 \mathrm{Cr}$ after plasma nitrided at $823 \mathrm{~K}$ for $90 \mathrm{ks}$.

すものと推測される.

$823 \mathrm{~K}$ で $90 \mathrm{ks}$ 窒化した試料の空化層を構成する相を同定す るために行った XRD の結果を Fig.3に示す. 図から判るよう に $\alpha-\mathrm{Fe}, \gamma^{\prime}-\mathrm{Fe}_{4} \mathrm{~N}$ 及び $\mathrm{CrN}$ の三相で窒化層が構成されている.

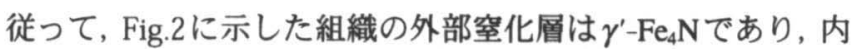
部窒化層は, マトリックス $\alpha-\mathrm{Fe}$ 中にC $\mathrm{CN}$ が分散析出した窒化 層から構成されていると判断される.このことは, Fig.2に示 した $2-3 \mu \mathrm{m}$ の外部窒化首は $\mathrm{Fe}$ と $\mathrm{N}$ のにより構成されてい ることを示している. しかし, 窒化前にはCrはF $\mathrm{F}$ 中に均一に 固溶していたはずであるので, 固溶 $\mathrm{Cr}$ は試料表面にも存在す るものと推測される.この推測からは上記の外部空化層の構

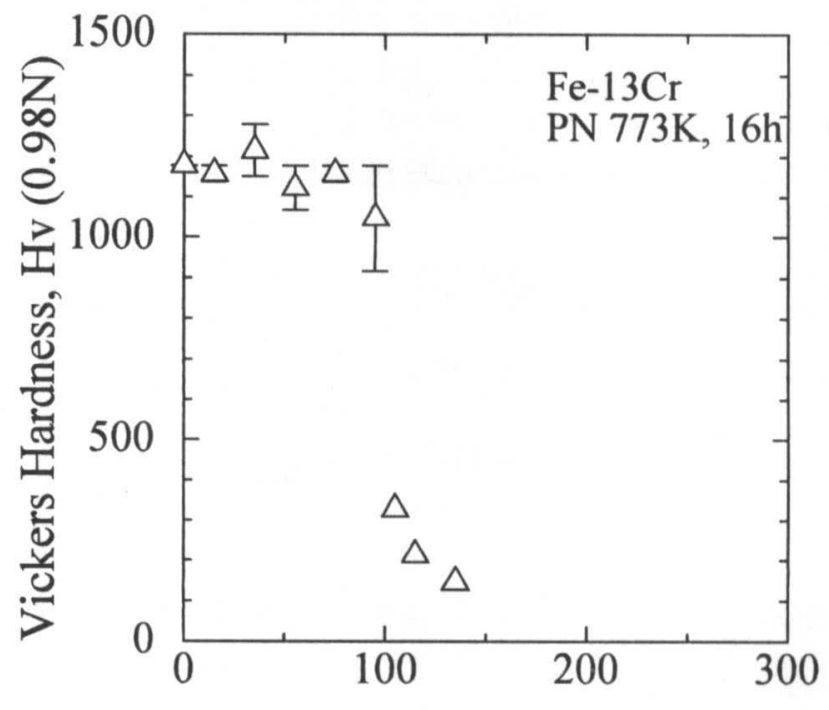

Distance from the surface, $\mathrm{d} / \mu \mathrm{m}$

Fig.4 Hardness profile on the cross section of $\mathrm{Fe}-13 \mathrm{Cr}$ after plasma nitrided at $773 \mathrm{~K}$ for $57.6 \mathrm{ks}$.

成は $\gamma^{\prime}-\mathrm{Fe}_{4} \mathrm{~N}$ とするよりも $\gamma^{\prime}-(\mathrm{Fe}, \mathrm{Cr})_{4} \mathrm{~N}$ とするべきであろう. この解明にはX線光電子分光法などによる詳細な研究を行う ことにしている.

上記の組織におけるビッカース硬さ分布をFig.4に示す. 表 面硬さはほぼHv1000 に到達し, 窒化層先端まで Hv1000 を維 持している. 窒化層先端で硬さは急激に未窒化域の硬さまで 低下している.このような硬さ分布はFig.2に示した組織と同 様に既に報告 ${ }^{11)}$ されているものと類似する典型的な窒化層の 硬さ分布である. 以上のことから $823 \mathrm{~K}$ 以下における $\mathrm{Fe}-13 \mathrm{Cr}$ の窒化機構は次のように定性的に説明できる.

窒化中に窒素が試料内部へ拡散して, 窒素との親和力が強 いクロムと窒素が反応する. そして, 窒化クロム析出物を析 出し, 更に表面での固溶窒素濃度が濃化すると外部窒化層を 形成する. このような場合, 内部窒化層の硬さの上昇は, 溶 質元素の全てが窒化中に窒化物として析出したと仮定すると, 析出析出窒化物の体積比の平方根に比例する. このことは, $\mathrm{Fe}-\mathrm{T}$ 合金の場合について報告されている(2)強化機構から類推 できる.

温度 $823 \mathrm{~K}$ 以下の窒化では上述のように典型的な窒化層組織 を得たが, このような硬さ分布では面圧の高い摩耗条件にお いて亀裂が発生すると, 容易に窒化層先端に達することは既 述のとおりである. したがって, 大きな荷重の下で良好な耐 摩耗性を示すためには窒化層の組織とその性質の改善が望ま れる. 例えば，硬質表面膜では膜と基板との間に大きなせん 断応力が作用するのに対して, 傾斜機能材料のように硬さプ ロファイルを傾斜化すると深さ方向に沿って応力が連続的に 緩和される ${ }^{13)}$.このことは面圧の高い摩擦条件下での使用に 好良な結果をもたらす。 $\mathrm{Fe}-3 \mathrm{Cr}$ のような低合金や日本工業規 格 (以下，JIS)の SCM 415 鋼のような低合金鋼を窒化すると 
このような硬さ傾斜プロファイルを得る.このような硬さ傾 斜化は反応析出型の空素拡散機構により容易に理解できる ${ }^{14}$. 窒化機構は通常, 以下のフィックスの第 1 法則により説明で きる.

$$
\lim _{\Delta x \rightarrow 0}\left\{v D_{C r}\left(\frac{\partial N_{C r}^{x}}{\partial x}\right)_{x=E+\Delta x}+D_{N}^{I N}\left(\frac{\partial N_{N}^{x}}{\partial x}\right)_{x=E-\Delta x}\right\}=0
$$

ここで, $\mathrm{D}_{\mathrm{Cr}}, \mathrm{D}_{\mathrm{N}}, \mathrm{E}$ はそれぞれ $\mathrm{Cr}$ の拡散係数, $\mathrm{N}$ の拡散係数, および窒化先端である.この式は,

(1) 窒化物を形成する合金元素 $\mathrm{Cr}$ と窒素との反応が常に窒化 先端で生じる.

(2) 未窒化域中の固溶 $\mathrm{Cr}$ が窒化層先端へ拡散する速度は窒素 の拡散速度より遥かに小さく無視する.

という仮定の下に解いている. 従って, 窒化層の成長は主に 窒素の拡散により支配される. また, 拡散した窒素は窒化層 内部に行くほどその濃度が緩やかに低下するので, 低Cr合金 では窒素と反応し, クロム窒化物を形成する $\mathrm{Cr}$ が少なく, 硬 さ分布はほぼ窒素の拡散プロファイルと同様に傾斜的である. 一方, 高 $\mathrm{Cr}$ 合金では固溶 $\mathrm{C}$ 濃度が高いため, 窒化先端ではCr がすぐに浸透した窒素と反応し, クロム窒化物を析出し, 窒 化層全体にほぼ一定の硬さ上昇が得られる.これらの窒化特 性は上記の(1)，(2)を仮定しているにもかかわらず，ほぼ実験 結果を説明できる. しかしこのような仮定を取り除き, 窒化 中に窒素だけでなく固溶 $\mathrm{Cr}$ も拡散することを考慮すると, 窒 化層特性の設計に必要なパラメーターが増えるので, 窒化組 織，硬さプロファイルなどの窒化特性をより詳細に制御でき ることが予測される. Cr 拡散させるための重要な因子の一 つは窒化温度である. そこで, 本研究ではこのような仮定を 立証するために窒化温度を通常の工業的空化温度範囲 (773$843 \mathrm{~K})^{(5)}$ より高(温度でプラズマ窒化を行った.

3.2 窒化温度 $T>823 \mathrm{~K}$ におけるプラズマ窒化

窒化層の組織変化に及ぼす窒化温度の影響を検討するため にプラズマ窒化を 873 K で行った. 873 K で 176.4 ks プラズマ 窒化した試料の組織を Fig. 5 に示す. $\mathrm{Fe}-13 \mathrm{Cr}$ 合金の内部窒化 層は, 明るい部分と暗い部分とが $10-15 \mu \mathrm{m}$ の幅で交互になつ た編状の組織が試料表面から $280-300 \mu \mathrm{m}$ まで成長し, かつそ れぞれのストライプの幅が試料表面に平行であることが特徵 である.これは窒化中の拡散によって生じた組織であって, 局部的変形によって生じた組織ではないことを意味している. この編状組織の明暗はそれぞれのストライプの耐食性が異な ることを示している. 反応性拡散の理論的考察から窒化層先 端や内部酸化層先端において溶質濃度の逆拡散は知られると ころであるので, クロム濃度がそれぞれのストライプで異 なっていると推察される.

$\mathrm{Fe}-13 \mathrm{Cr}$ 合金を $873 \mathrm{~K}$ で $176.4 \mathrm{ks}$ プラズマ窒化後の試料断面

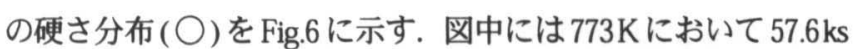
プラズマ空化した $\mathrm{Fe}-13 \mathrm{Cr}$ 合金の断面における硬さ分布 $(\Delta)$ も参考に示している. 従来報告されているように窒化層の成
長過程が主に窒素の拡散支配とすれば(6), 硬さ分布はFig.6 中 に $\triangle$ で示したようになる. 即ち, 既述 (Fig.4参照)のように, 窒化層中の硬さはほほ一定である.これに対して, 873Kにお いて窒化すると図中に○で示すように表面硬さはHv1200から Hv600 に低下しているが, 硬さの上昇と低下を絽返しながら 断面における深さは窒化首先端に向かってHv1000以上まで上 昇している. このような硬さ分布は従来の硬さ分布 $(\Delta)$ と は異なり, 硬さの昇降を絽り返しながら表面から窒化層先端 まで上昇する硬さプロファイルを示し，窒化層全体として逆 の傾斜を示している. この硬さの上昇と低下の繰返しの幅は

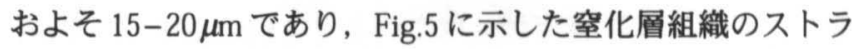
イプの幅にほぼ一致している.

さらに, 窒化層でのCr濃度分布を $\mathrm{Cr}$ 濃度の変化に注目して

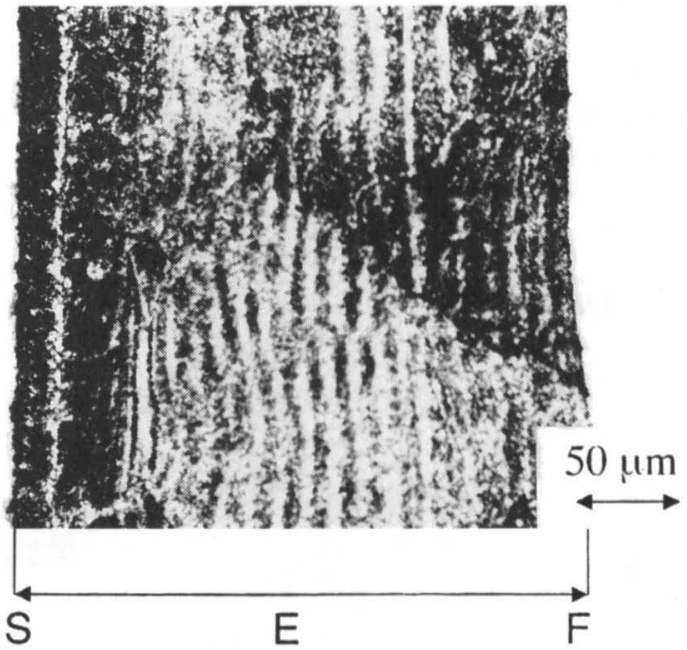

Fig.5 Microstructure of $\mathrm{Fe}-13 \mathrm{Cr}$ after plasma nitrided at $873 \mathrm{~K}$ for $176.4 \mathrm{ks}$.

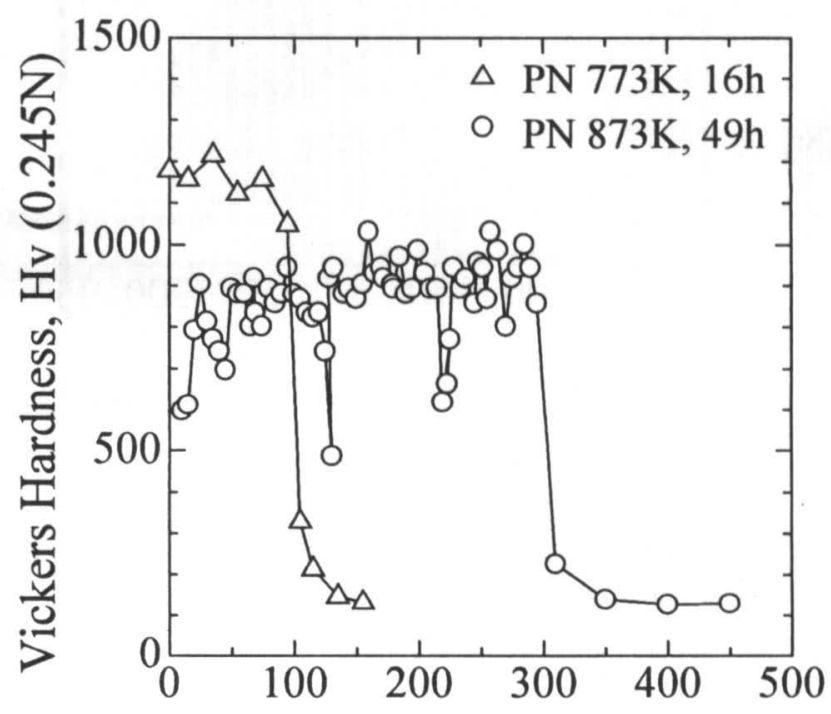

Distance from the surface, $d / \mu \mathrm{m}$

Fig.6 Hardness profile on the cross section of $\mathrm{Fe}-13 \mathrm{Cr}$ alloys after plasma nitrided at $773 \mathrm{~K}$ for $57.6 \mathrm{ks}$ and $873 \mathrm{~K}$ for $176.4 \mathrm{ks}$. 
定性的に Fig.7に示す． 図からわかるように表面では Cr 濃度 が一番高く，そして内部に向けて Cr 濃度が上昇と減少を繰り 返している.この空化層内部のCr濃度の低い部分と, Cr 濃度 の高い部分の幅はほほFFig.5に示した組織のストライプ幅と一 致している.

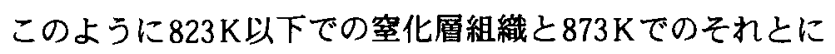
は大きな差異がある.このことは窒化機構の違いに基づくも のと推測され, 単に窒素が内部へ一方向的濃度勾配を形成す るような抬散ではなく, 溶質元素である $\mathrm{Cr}$ が内部から空化首 先端へ逆拡散することによって発現する組織と考えられる。 即ち, $873 \mathrm{~K}$ 以下の温度域ではこのような $\mathrm{Cr}$ の逆拡散は䫓著 には現れず, $873 \mathrm{~K}$ 以上の温度域において顕著に発現したため に Fig.5に示したような組織になったものと考えられる.

各窒化温度における窒化層成長の速度定数と温度の関係を Fig.8に示す. 図から $873 \mathrm{~K}$ における空化首の成長の速度定数 は測定値と823K以下の温度域での測定值から $873 \mathrm{~K} に$ 外挿し た値とは約10倍の違いがあることが判る.この違いは窒化層 の成長機構を以下のように考えることによって定性的に説明 される.

Table 1 に示すように $\boldsymbol{\alpha}$ - Fe 中の Cr の拡散速度は $873 \mathrm{~K}$ と $823 \mathrm{~K}$ とでは約 7.5 倍速くなっているのに対して, Nは約 1.8 倍速く

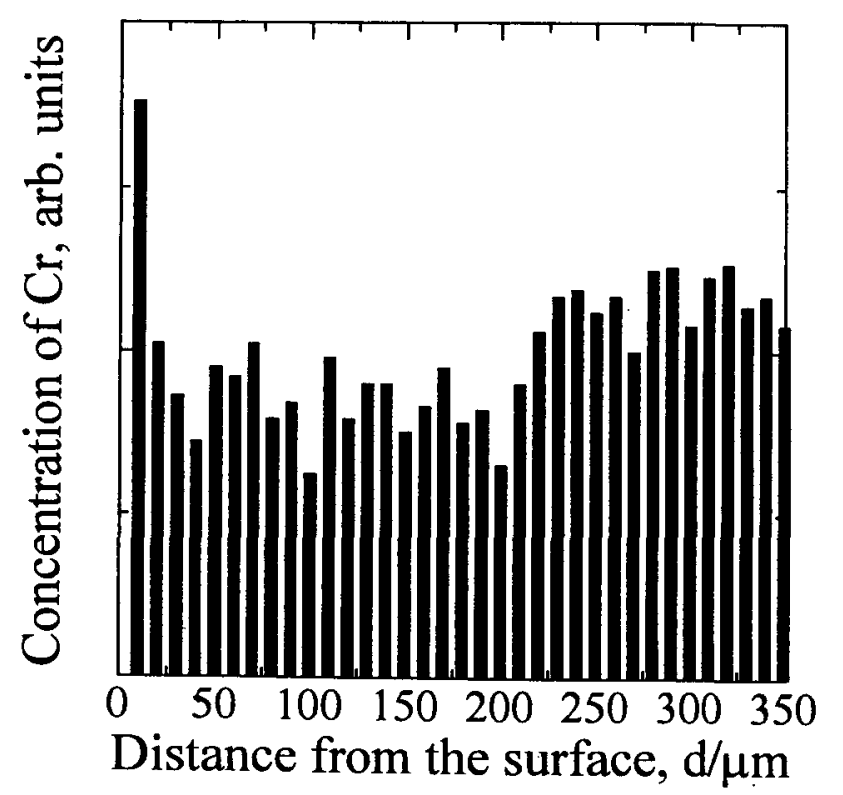

Fig.7 Concentration of $\mathrm{Cr}$ on the cross section of $\mathrm{Fe}-13 \mathrm{Cr}$ after plasma nitrided at $873 \mathrm{~K}$ for $176.4 \mathrm{ks}$.
なっている. 即ち, 窒化首先端へ内部から逆拡散する $\mathrm{Cr}$ 量が 多くなっていることを示唆している. しかし, ある一定の距 離を搪散する $\mathrm{C}$ の速度よりも $\mathrm{N}$ の拡散速度が速いので, 内部 公化首中よりも固溶クロム㗳度の高い領域へNが拡散すること になる.このために固溶クロム浱度の高い領域を残しながら $\mathrm{N}$ が内部へ拡散する. 固溶クロム濃度の高い領域は良好な耐食 性を示すためにFig.5に示したように明るい領域を生成してい る. 一方, Nが内部への拡散する主たる経路は母相の $\alpha-\mathrm{Fe}(\underline{\mathrm{Cr}})$ と考えられるので, その経路の有効断面稙は $\mathrm{CrN}$ が析出する ことにより小さくなると考えられ，このために窒化層の成長 速度を減速させる. また, Fig.6に示した硬さ分布についても 上記のような成長機構を考えると析出クロム窒化物の分布に 同期しているものと推測され，同様に定性的に説明される. 更に, 表面から内部になるほど固溶 $\mathrm{Cr}$ の濃度が大きなくなる ので浸透した $\mathrm{N}$ との反応が進行して内部ほど析出 $\mathrm{CrN}$ 量が多 くなるものと推測される.このことが試料表面から内部に向 かって硬さの逆傾斜を発現させた原因であろうと推測される.

Fig.9 は上記の窒化試料における耐スカッフ試験結果を示 す.図中の耐スカッフ值700Nはピストンリングに求められる 目標値である ${ }^{17}$. 図からわかるように編状組織の試料(プラズ マ室化した $\mathrm{Fe}-13 \mathrm{Cr}$ ) が炭素を含まないにもかかわらず，よい

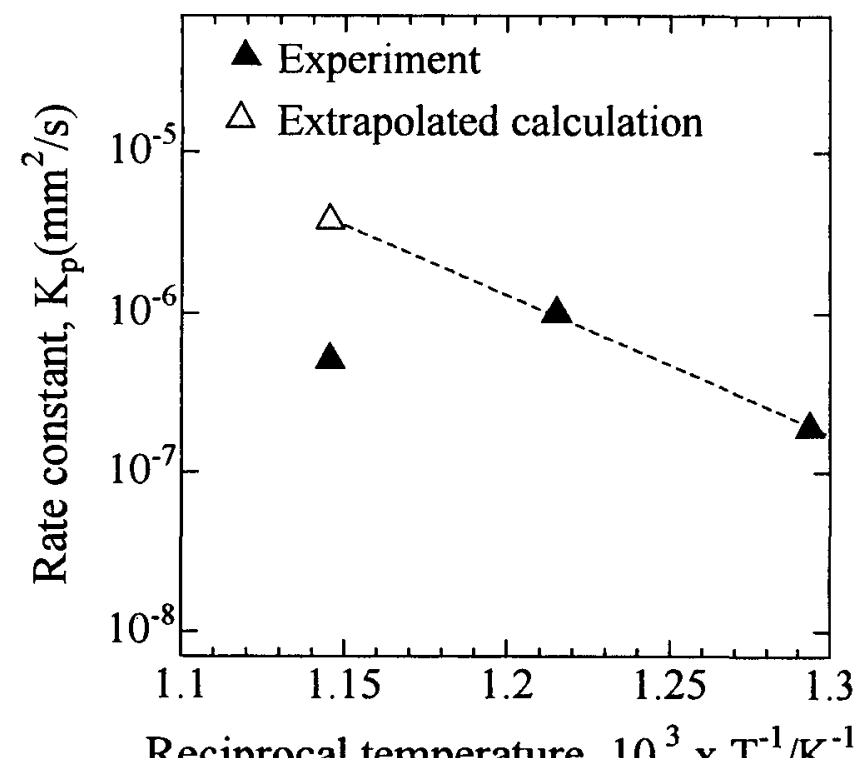

Fig.8 Temperature dependence of nitriding front rate constant of Fe-13Cr alloy.

Table 1 Diffusion coefficient of $\mathrm{N}$ and $\mathrm{Cr}$ in $\alpha$-Fe as calculated at several temperatures ${ }^{16)}$.

\begin{tabular}{|c|c|c|c|}
\hline \multirow{2}{*}{ Diffusion Coefficient } & \multicolumn{3}{|c|}{ Temperature } \\
\cline { 2 - 4 } & $773 \mathrm{~K}$ & $823 \mathrm{~K}$ & $873 \mathrm{~K}$ \\
\hline $\mathrm{D}_{\mathrm{N}}, \mathrm{cm}^{2} / \mathrm{s}$ & $0.33 \times 10^{-7}$ & $0.687 \times 10^{-7}$ & $1.305 \times 10^{-7}$ \\
\hline $\mathrm{D}_{\mathrm{Cr}_{\mathrm{r}}} \mathrm{cm}^{2} / \mathrm{s}$ & $0.136 \times 10^{-15}$ & $1.323 \times 10^{-15}$ & $9.92 \times 10^{-15}$ \\
\hline
\end{tabular}



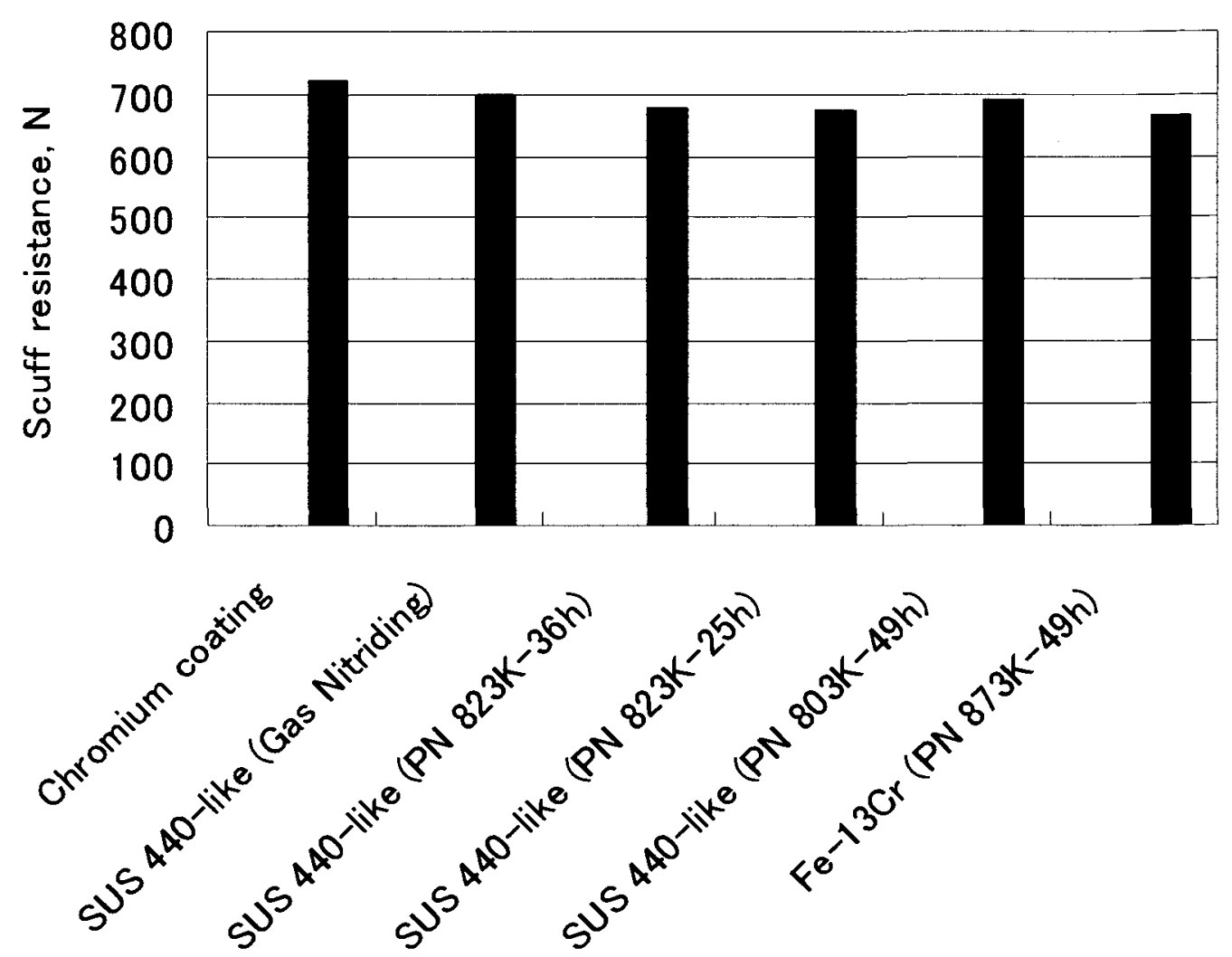

Fig.9 Scuffing resistance of several plasma nitrided specimens.

耐スカッフ性を示した. 従って, このような窒化組織を制御 することによって，より優れた摩耗特性を期待できる. 更に より精密な制御を行うこと，具体的には例えば，上記の組織 のストライプ幅の制御, 硬さプロファイルの制御などにより, 興味深い窒化層特性を設計できることも考えられる。これら の制御を行うには窒化温度の他にガス組成，冷却速度などが 重要なパラメーターであると考えられる. 現在これらについ ては詳細な研究を進めている.

\section{4 まとめ}

窒素と溶質原子であるCrの拡散を制御して新しい窒化層組 織を創製するために, $\mathrm{Fe}-13 \mathrm{Cr}$ 合金を773-873Kの温度域でプ ラズマ窒化して窒化層の材料組織学的評価を行った. その結 果, 主として以下の結論を得た.

(1) $873 \mathrm{~K}$ においてプラズマ窒化すると従来報告されていない 縞状組織を得た。

(2)この編状組織はおよそ $15-20 \mu \mathrm{m}$ の間隔であり，硬さ分布 もこの縞状組織に対応した振動を示した.

(3)この縞状組織を示した試料の公化首断面における硬さ分布は 試料表面においてHv700程度を示したが, 内部に向かって 硬化と軟化を示しながら全体として効果を示し，窒化層先端 でHv1100を示した. 即ち, 硬さ分布の逆傾斜化を示した.

(4)このような組織や硬さ分布についての報告はこれまでない が, 試料表面から内部への窒素の一方向の侵入拡散だけで
なく，溶質元素の $\mathrm{Cr}$ の内部から窒化層先端への逆拡散を 生じさせたことによって発現した.

(5)このような溶質元素も拡散させることによって窒化層の組 織制御を可能にする新しい組織制御法として提案した.

\section{文献}

1) B.Edenhofer and T.J.Bewley: "Low-temperature ion nitriding ...", Publ. Met. Soc., 181(1976)7-13.

2) K.-T.Rie and E.Broszeit: "Plasma diffusion treatment and $\cdots "$, Surface and Coatings Technology, 76-77(1995)425-436.

3) K.-T.Rie: "Recent advances in plasma diffusion process", Surface and Coatings Technology, 112(1999)56-62.

4) J.M.Priest, M.J.Baldwin, et.al: "Low pressure r.f. nitriding of austenitic $\cdots "$ ", Thin Solids Films, 345(1999)113-118.

5) C.Alves Jr., J.De Anchieta Rodrigues and A.E.Martinelli: "Growth of nitrided layers on $\mathrm{Fe}-\mathrm{Cr}$ alloys", Material Science and Engineering, A279(2000)10-15.

6) H.Kuwahara, H.Matsuoka, et.al: "Plasma Nitriding of Fe-18Cr9Ni in ․", Oxidation of Metals, 36 No.1/2(1991)143-156.

7) M.Berg, C.V.Budtz-Jørgensen, et.al: "On plasma nitriding of steels", Surface and Coatings Technology, 124(2000)25-31.

8) M.Uma Devi and O.N.Mohanty: "Plasma-nitriding of tool steels for combined *.", Surface and Coatings Technology, 107(1998) $55-64$. 
9) W.Kovacs and W.Russel: "An introduction to ion nitriding...", Proc. Int. Conf. Ion Nitriding, Cleveland, OH, 15-17 September 1986, ASM International, (1986)9-17.

10) M.Berger, U.Wiklund, et.al: "The multilayer effect in abrasion ...", Surface and Coatings Technology, 116-119(1999)11381144.

11）高田潤, 松本宏之, 桑原秀行 : " 鉄合金のプラズマ処理…", 粉体および粉末冶金, 39(1992)121-124.

12) 桑原秀行, 高田潤: "鉄合金のプラズマ空化", 粉体および 粉末治金, 41(1994)1341-1351.

13) H.A.Bruck: "A one-dimensional model for designing functionally graded materials $\cdots "$ ", Intl. J. of Solids and Structures, 37(2000)6383-6395.

14) Y.Sun and T.Bell: "Mathematical modelling of plasma nitriding", Proceedings 9th International Congress on Heat Treatment and Surface Engineering (IFHT), Nice, France, Sept. 1994, Ed. F.Moreaux, (1994)385-394

15) 山中久彦: イオン空化法, 日刊工業新聞社, (1976)10.

16）金属データブック，日本金属学会編，丸善株式会社, (1974).

17) P.N.Bindumadhavan, S.Makesh, et.al: "Aluminizing and subsequent nitriding of", Surface and Coating Technology, 127 (2000)252-259. 